\title{
Analisis Gangguan Arus Hubung Singkat Trafo Distribusi 48-PT- 33-7 Menggunakan ETAP (Studi Kasus Di Perumahan PT. Badak NGL)
}

\author{
Abdul Zain ${ }^{1 *}$, Rifki Chairul Afwan ${ }^{2}$ \\ Program studi Teknik Elektro, Sekolah Tinggi Teknologi (STITEK) Bontang, \\ Kalimantan Timur, Indonesia \\ jainbtg2013@gmail.com
}

\begin{abstract}
The high frequency of short circuit current fault in power grid PT. Badak NGL Bontang in 2017 becomes a serious problem. One of them is the Short Circuit at Distribution Transformer 48-PT-33-7 which resulted in a feeder 48-FDR-33 trip and cut off the power to all connected loads. This research is conducted to know the value of short circuit current fault by manual calculation and compared with the simulation software ETAP 12.6 which made system modeling refers to real network configuration in the field. After that, ETAP conducted simulation and short circuit analysis in transformer 48-PT-337. The calculation result is known that the short circuit current value between manual calculation and ETAP simulation is relatively same, ie 553,8 A / $555 \mathrm{~A}$ (one phase to ground), 891,47A / $885 \mathrm{~A}$ (two phase), 918,16 A/950 A (two phase to ground), $1029.41 \mathrm{~A} / 1022 \mathrm{~A}$ (three phases). From the simulation also known the coordination sequence of the protection system works properly when the fault occurs. So from these two results indicate that the installed protection system is in accordance with the standard in securing the power grid from short-circuiting current fault.
\end{abstract}

Keywords : $\quad$ Short circuit, distribution transformer, feeder, ETAP simulation

\begin{abstract}
Abstrak: Tingginya frekuensi gangguan arus hubung singkat pada jaringan tenaga listrik di PT. Badak NGL Bontang pada tahun 2017 menjadi permasalahan serius. Salah satu diantaranya ialah Arus Gangguan Hubung Singkat Trafo Distribusi 48PT-33-7 yang menyebabkan Feeder 48-FDR-33 trip dan memutus aliran listrik terhadap semua beban yang terhubung. Penelitian ini dilakukan untuk mengetahui besarnya nilai gangguan arus hubung singkat dengan cara perhitungan manual dan dibandingkan dengan simulasi software ETAP 12.6 yang dibuat pemodelan sistem mengacu pada konfigurasi jaringan real di lapangan. Setelah itu pada ETAP dilakukan running simulasi dan short circuit analisis di Trafo 48-PT-33-7. Hasil dari perhitungan diketahui nilai arus hubung singkat antara perhitungan manual dan simulasi ETAP relatif sama, yakni 553,8 A/555 A (satu fase ke tanah), 891,47 A/885 A (dua fase), 918,16 A/950 A (dua fase ke tanah), 1029,41 A/1022 A (tiga fase). Berdasarkan simulasi, diketahui juga urutan koordinasi sistem proteksi bekerja dengan semestinya ketika gangguan terjadi. Kedua hasil tersebut menunjukkan bahwa sistem proteksi yang terpasang sudah sesuai standar dalam mengamankan jaringan dari gangguan arus hubung singkat.
\end{abstract}

Kata kunci : Hubung singkat, trafo distribusi, feeder, simulasi ETAP

\section{PENDAHULUAN}

Dalam proses penyaluran tenaga listrik, masih banyak muncul gangguan-gangguan yang terjadi, antara lain gangguan tiga fase, antar fase maupun gangguan fase ke tanah. Penyebabnya bermacam-macam antara lain bisa terjadi karena beban tidak seimbang atau beban berlebih, terjadinya internal failure yang disebabkan usia peralatan. Begitupun halnya dengan Industri Pengolahan dan Pencairan Gas Alam PT Badak NGL Bontang Kalimantan Timur [1].

Berdasarkan record data gangguan sistem tenaga listrik di PT Badak NGL pada awal tahun 2017, jaringan sistem tenaga listrik di area perkantoran tercatat beberapa kali mengalami gangguan yang mengakibatkan trip nya jaringan distribusi antara lain terjadinya Short Circuit Trafo 48-PT-33-7.

Untuk mencari solusi dari kasus tersebut, diperlukan alat atau sistem yang dapat menganalisis besarnya arus gangguan hubung singkat, serta menentukan setting peralatan proteksi yang harus dipasang. Oleh karena itu digunakan suatu program simulator yaitu program ETAP (Electrical Transient Analyzer Program) Power Station, sehingga nilai parameter pengaman yang digunakan dapat disetting dengan tepat sesuai dengan besarnya gangguan arus hubung singkat [2]. 


\section{METODOLOGI PENELITIAN}

\section{A. Pengumpulan data}

Pelaksanaan penelitian ini berlangsung selama dua bulan dimulai dari Maret 2017 sampai dengan April 2017. Kegiatan penelitian ini dilakukan di jaringan distribusi untuk area Perumahan PT Badak NGL, Bontang, Kalimantan Timur, khususnya di bagian Electrical Section, Maintenance Department. Metode yang digunakan untuk mendapatkan data-data dalam penelitian ini diperoleh dari studi literatur, observasi lapangan dan data hasil pengujian yang dilakukan oleh Crew Maintenance Electric PT Badak NGL.

Dalam pelaksanaan penelitian terdapat berbagai literatur terkait judul yang dibahas. Banyak literatur yang mendukung kesuksesan penelitian ini diantaranya:
a. Sistem distribusi tenaga listrik
b. Sistem proteksi distribusi tenaga listrik
c. Perhitungan arus hubung singkat
d. Simulasi dengan software ETAP

Selama pelaksanaan penelitian, banyak data pendukung terkait objek yang diteliti serta pendukungpendukung lainnya. Data tersebut adalah sebagai berikut:

1. Data Jaringan Distribusi Feeder 48 - FDR-33 untuk Trafo 48-PT-33-7 Feeder 48-FDR-33 merupakan salah satu jaringan distribusi tenaga listrik di PT. Badak yang berfungsi untuk menyalurkan daya ke area Perumahan PC-III yang terdiri dari 9 trafo distribusi, yakni 48-PT-33-1 s/d 48-PT-33-9 [1].

Berikut terlampir pada gambar 1 mengenai diagram satu garis jaringan feeder distribusi 48-FDR-33 untuk supply daya listrik ke area perumahan PT. Badak NGL area PC 3 melalui 11 trafo distribusi.

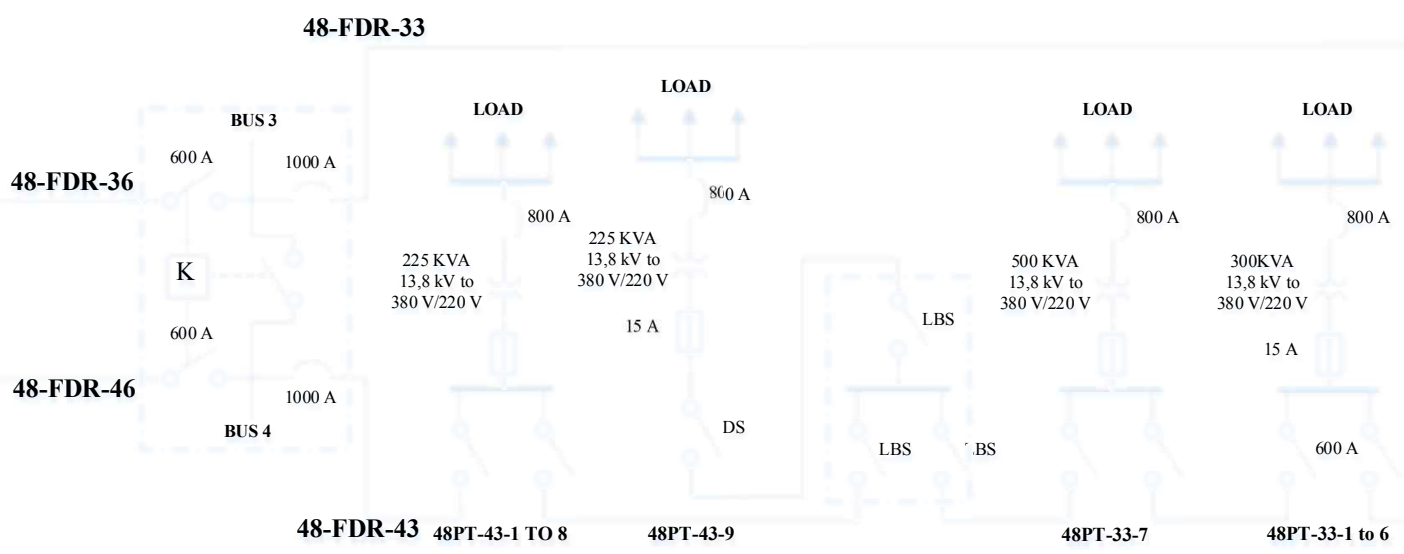

Gambar 1. One Line Diagram Feeder 48-FDR-33

Sumber: PT Badak NGL

2. Data Peralatan Trafo Distribusi 48- PT-33-7

Trafo 48-PT-33-7 merupakan salah satu trafo distribusi di PT Badak NGL yang menyuplai beban area perumahan PC-3. Adapun spesifikasi trafo antara lain:

$\begin{array}{llll}\text { Voltage } & : 13,8 \mathrm{KV} / 380 \mathrm{~V} / 220 \mathrm{~V} & \text { Phase } & : 3 \text { Phase } \\ \text { Rated Power } & : 500 \mathrm{kVA} & \text { Frequency } & : 50 \mathrm{~Hz} \\ \text { Impedance } & : 4,02 \% & \text { Cooling } & : \text { ONAN }\end{array}$

Oil Volume : $: 800 \mathrm{~L}$ 
101 Abdul Zain, Rifki Chairul Afwan. Analisis Gangguan Arus Hubung Singkat Trafo Distribusi 48-PT-33-7 Menggunakan ETAP (Studi Kasus Di Perumahan PT. Badak NGL)

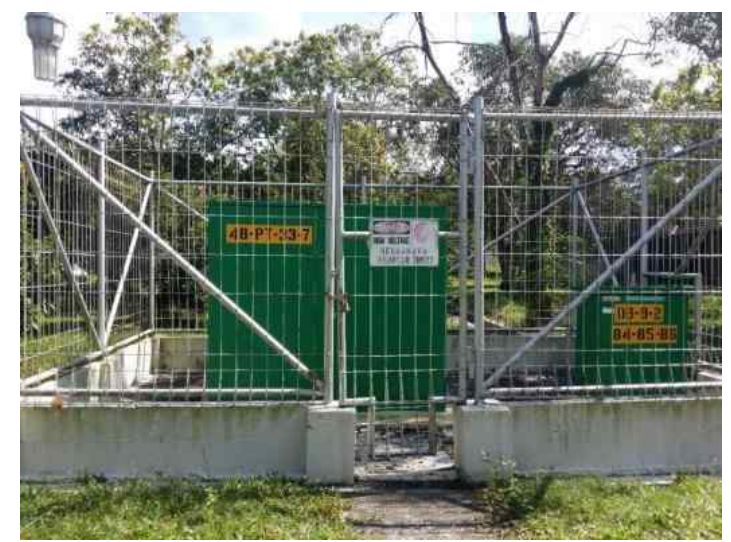

Gmbar 2 Lokasi Trafo 48-PT-33-7

Sumber: PT Badak NGL

3. Trafo Arus / Current Transformer (CT)

Trafo arus yang digunakan pada feeder 48-FDR-33 yaitu di dalam kubikel adalah sebagai berikut sesuai dengan setting yang tertera pada sistem software Relay [3].

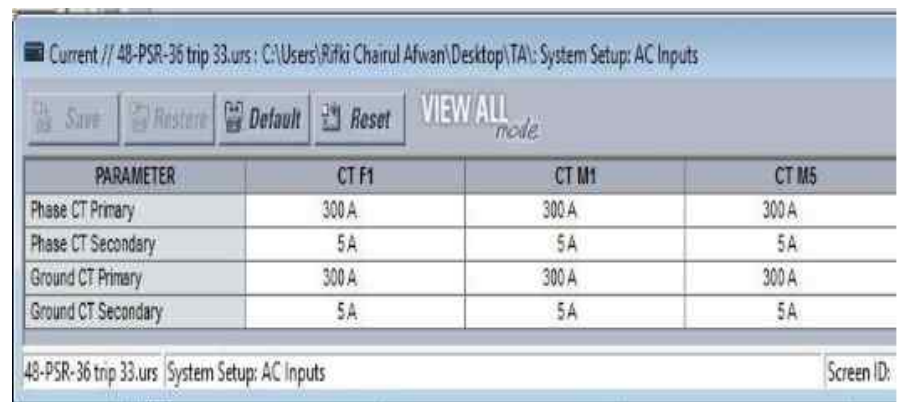

Gambar 3. Data Rasio CT

Sumber: GE Multilin

a) Trafo arus untuk mengukur arus setiap fase (fase A, B dan C) menggunakan CT ratio $300: 5 \mathrm{~A}$

b) Trafo arus untuk mengukur arus grounding menggunakan CT ratio 300:5A.

4. Data Relay Proteksi UR F35 untuk Proteksi Feeder 48-FDR-33

Relay proteksi feeder 48-FDR-33 menggunakan relay digital UR-F35 GE Multilin [4] dengan fungsi proteksi dan setpoint adalah sebagai berikut:

a) Phase instantaneous overcurrent relay (50): $\quad 600 \% \times C T=30 \mathrm{~A}$ secondary

b) Phase time overcurrent relay (51):Time dial: 0,11

$$
=1800 \mathrm{~A} \text { primary }
$$

Curve: IAC Extremely inverse $90 \% x C T=4.5 \mathrm{~A}$ secondary $=270$ A primary

c) Ground instantaneous overcurrent relay (50G):

$$
\begin{aligned}
9,3 \% \times C T & =0.465 \mathrm{~A} \text { secondary } \\
& =27,9 \mathrm{~A} \text { primary }
\end{aligned}
$$

d) Ground time overcurrent relay (51G):

Time dial: 0,11

Curve: IAC Extremely inverse 9,3\% $x C T=0.465 \mathrm{~A}$ secondary $=27,9 \mathrm{~A}$ primary 


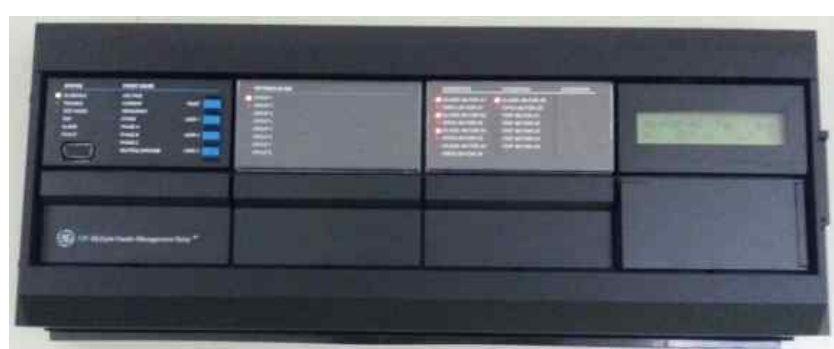

Gambar 4. Relay UR F35 untuk Proteksi Feeder 48-FDR-33 Sumber: PT Badak NGL

\section{Data Pemutus Tenaga Listrik (PMT)}

PT Badak NGL memiliki alat untuk menghubungkan jaringan distribusi tenaga listrik dari feeder ke beban menggunakan jenis PMT yaitu Disconnecting Switch (DS) yang dipasang dalam kubikel trafo distribusi 48-PT-33-7. Disconnecting switch adalah saklar pemutus yang didesain tidak bisa terbuka pada saat arus beban yang melewatinya masih ada [5]. Biasanya disconnecting switch dipasang untuk mengisolasi peralatan-peralatan yang mungkin tersupply daya besar dalam kata lain Disconnecting Switch merupakan peralatan pemisah, yang berfungsi untuk memisahkan rangkaian listrik dalam keadaan tidak berbeban.

\section{B. Langkah Kerja Penelitian}

a. Perhitungan Arus Hubung Singkat dengan Perhitungan Manual

Perhitungan arus hubung singkat pada feeder 48-FDR-33 dilakukan dengan mencari nilai daya aktif hubung singkat (MVAsc) masing- masing generator yang menyuplai bus feeder 48FDR-33 [6]. Setelah mengetahui nilai MVAsc dari generator maka selanjutnya untuk menghitung arus hubung singkat pada feeder 48-FDR-33.

b. Perhitungan Arus Hubung Singkat dengan Simulasi ETAP.

Tahapan-tahapan perhitungan arus hubung singkat pada feeder 48-FDR-33 menggunakan metode simulasi ETAP [1] adalah sebagai berikut:

1. Membuat data tabel pembebanan kondisi $80 \%$ untuk simulasi ETAP

Data tabel diperlukan untuk memudahkan dalam pengisian parameter pembebanan kondisi full load dengan kondisi $80 \%$, sehingga hasil penelitian dapat dilihat perbedaan nilai arus hubung singkatnya. Berikut terlampir pada tabel 1.

Tabel 1. Data Pembebanan Kondisi 80\%

\begin{tabular}{|c|c|c|c|c|c|c|c|c|}
\hline \multicolumn{9}{|c|}{ DATA JARINGAN FEE DER $48 F$ DR-33 } \\
\hline \multirow{2}{*}{ No } & \multirow{2}{*}{ TAGIRAFO } & \multicolumn{2}{|c|}{ TEGANGAN } & \multirow{2}{*}{$\begin{array}{c}\text { RATIVG } \\
\text { FLSE } \\
(A)\end{array}$} & \multirow{2}{*}{$\begin{array}{c}\text { RIIING } \\
\text { CB } \\
(A)\end{array}$} & \multirow{2}{*}{$\begin{array}{c}\text { KAF.AGTAS } \\
\text { (kVA) }\end{array}$} & \multirow{2}{*}{$\begin{array}{c}\text { FUI LOAD } \\
\text { (KVA) }\end{array}$} & \multirow{2}{*}{$\begin{array}{c}500 \text {. LO.AD } \\
\text { (kVA) }\end{array}$} \\
\hline & & $\begin{array}{c}\text { PRAIER } \\
\text { (KV) }\end{array}$ & $\begin{array}{c}\text { SEKTNDER } \\
\mathrm{N}\end{array}$ & & & & & \\
\hline 1 & $4 \times P-33-1$ & 138 & 380 & 15 & 600 & 300 & 300 & 240 \\
\hline 2 & $480-33-2$ & 138 & 380 & 15 & 500 & 300 & 300 & 240 \\
\hline 3 & $4 \mathrm{NPT}-33-3$ & 138 & 380 & 15 & 600 & 225 & 225 & 180 \\
\hline 4 & $4305-334$ & 138 & 380 & 15 & $6 \infty$ & 225 & 225 & 189 \\
\hline 5 & $4 \mathrm{X} T-33-5$ & 138 & 390 & 15 & 500 & $3 \times 0$ & 300 & 248 \\
\hline है & 4 बIT $-33-6$ & 13,3 & 380 & 15 & 600 & 300 & 300 & 240 \\
\hline 7 & 4XI-33-7 & 128 & 390 & 15 & 800 & 500 & 500 & 400 \\
\hline 8 & $4 \times 2 \mathrm{~T}-33-8$ & 138 & 380 & 15 & 600 & 30 & 300 & 240 \\
\hline 9 & $43 \mathrm{gr}-33.9$ & 13.8 & 380 & 30 & 800 & 500 & 500 & $4 x$ \\
\hline 10 & 4 ST $-33-10$ & 138 & 380 & 30 & $B D$ & 225 & $n 3$ & 182 \\
\hline 11 & $4 \times 2 T-33-11$ & 179 & 380 & 30 & $8 x$ & 50 & 500 & $4 x$ \\
\hline 17 & AIPT-48.9 & 138 & 390 & 15 & 500 & 225 & 225 & 180 \\
\hline
\end{tabular}


103 Abdul Zain, Rifki Chairul Afwan. Analisis Gangguan Arus Hubung Singkat Trafo Distribusi 48-PT-33-7

Menggunakan ETAP (Studi Kasus Di Perumahan PT. Badak NGL)

2. Membuat One Line Diagram

One line diagram dibuat sesuai dengan data pada feeder 48-FDR-33 yaitu dimulai dari power grid, bus 3 \& 4, feeder 48-FDR-36 dan 46, feeder 48-FDR-33 hingga ke beban Trafo 48-PT-33-7.

Edit Yiew Project Library Bules Defaults Iools RevControl Real-Time Window Help

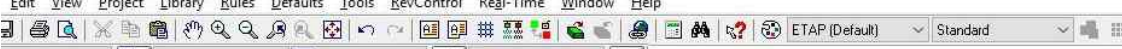

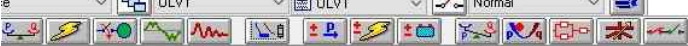

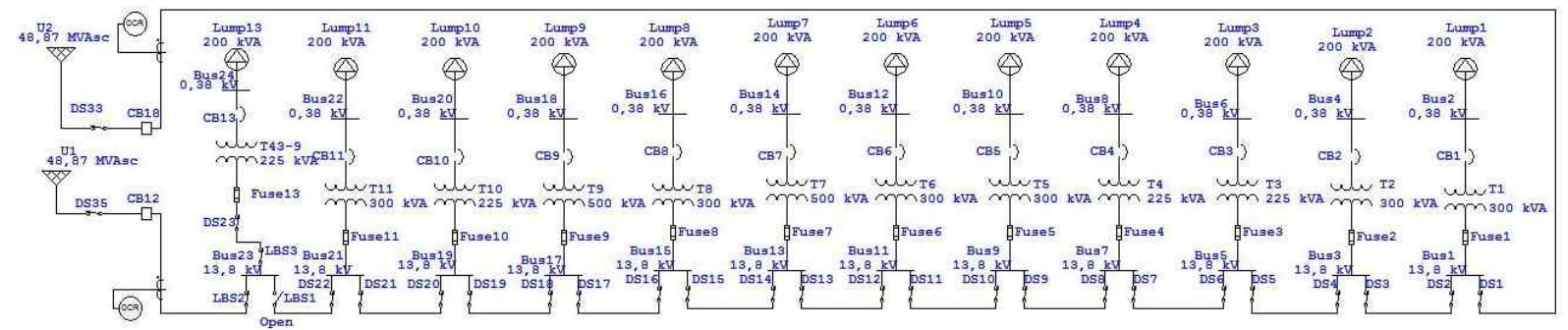

Gambar 5. Tampilan One Line Diagram pada Software ETAP 12.6

3. Mengisi Parameter Setiap Peralatan Listrik

a) Power Grid

Nilai parameter yang diisi untuk elemen Power Grid, yakni antara lain nilai power short circuit (MVAsc) sebesar 24,437 MVA dan nilai X/R sebesar 7,51 serta yang lainnya otomatis terisi.

b) Bus

Bus yang digunakan ada dua jenis yakni Bus untuk High Voltage dan Low Voltage. Untuk Bus High Voltage diisi dengan nilai $13,8 \mathrm{kV}$ dan Bus Low Voltage diisi dengan nilai $0,38 \mathrm{kV}(380 \mathrm{~V})$.

c) Fuse

Nilai parameter yang diisi adalah rating arusnya yakni sebesar 15A (continue) dengan tegangan max $15,5 \mathrm{Kv}$.

d) Circuit Breaker (CB)

$C B$ yang digunakan ada dua jenis yakni $C B$ untuk High Voltage dan Low Voltage. Untuk High Voltage diisi dengan nilai 1200 A dan Low Voltage diisi 630 A.

e) Relay Pengaman Feeder UR F35

GE Multilin dan CT

Relay yang digunakan adalah relay jenis Multi Function Relay. Untuk CT parameter nilainya diisi denga Rasio 300:5. Dan untuk relay, jenis yang digunakan adalah UR F-35 GE Multilin pada library, kemudian pada OCR parameter yang diisi adalah nilai Pickup nya yakni sebesar 0,093 dan Time Dial 0,06 dan selebihnya otomatis.

f) Trafo

Parameter yang diisi antara lain nilai tegangan Primer sebesar $13,8 \mathrm{kV}$ dan Sekunder sebesar $0,38 \mathrm{kV}$ (380 Volt). Selain tegangan, kemudian nilai Power Rating diisi sebesar $500 \mathrm{kVA}$. Parameter terakhir yang diisi adalah nilai Impedance yakni sebesar 4\% dengan typical X/R dan selebihnya otomatis.

g) Beban 
Parameter yang diisi antara lain nilai Power Rating sebesar $80 \%$ dari Power Rating Trafo. Kemudian disamping itu jenis beban (Load Type) disetting 60\% untuk beban Motor dan 40\% untuk beban Static.

4. Memilih Menu Load Flow Analysis

Tahapan ini merupakan langkah yang dilakukan untuk menguji aliran beban rangkaian yang telah dibuat. Apabila aliran daya tidak dapat dilakukan berarti terdapat beberapa kesalahan dalam membuat one line diagram atau dalam mengisi parameter peralatan listrik yang digunakan.

5. Melakukan Running Load Flow Analysis

Dengan melakukan pengujian aliran beban maka akan diperoleh besaran arus normal yang mengalir dari pusat pembangkit melalui feeder menuju ke beban. Besaran arus tergantung parameter beban yang digunakan.

6. Memilih Menu Short Circuit Analysis

Short circuit analisis dilakukan untuk simulasi gangguan pada bus atau feeder yang dikehendaki untuk diketahui besaran arus hubung singkat terjadi.

7. Melakukan Running Short Circuit Analysis

Hal ini dilakukan untuk melihat besaran arus gangguan hubung singkat pada bus yang terjadi gangguan.

\section{HASIL DAN PEMBAHASAN}

1. Kronologi Gangguan Hubung Singkat pada Feeder 48-FDR-33

Jaringan distribusi di Switchgear Area 9 dioperasikan dengan sistem radial tunggal, artinya semua beban 48-PT-33-1 s/d 11 hanya disuplai melalui satu feeder yaitu 48-FDR-33. Sehingga kelemahan sistem jaringan tersebut adalah pada saat gangguan terjadi di salah satu trafo distribusi maka akan mengakibatkan seluruh sistem jaringan di Feeder 48-FDR-33 akan black out (trip).

Berdasarkan data yang diperoleh mulai bulan Januari 2017 hingga bulan Maret 2017, telah terjadi beberapa kali trafo yang mengalami failure (short circuit) di area feeder 48-FDR-33 dan salah satunya adalah Trafo 48-PT-33-7. Pada Trafo 48-PT-33-7 setelah dilakukan pengecekan oleh petugas Maintenance Electrical Section ditemukan bahwa gangguan yang terjadi adalah gangguan 2 fase ke tanah (phase to phase to ground), dimana pada saat gangguan terjadi fuse yang terpasang pada proteksi trafo sudah bekerja untuk mengamankan gangguan over current phase to phase. Akan tetapi hal tersebut belum cukup mengamankan feeder dari gangguan yang terjadi karena gangguan arus bocor phase to ground nya masih terjadi. Hal tersebutlah yang mengakibatkan tripnya feeder 48-FDR33 yang dideteksi oleh Relay UR-F35 GE Multilin dikarenakan tidak ada alat proteksi untuk melindungi jaringan distribusi dari gangguan arus hubung singkat phase to ground di sisi trafo. Selama pengecekan dan perbaikan berlangsung, maka semua beban jaringan area feeder 48FDR-33 tersebut tidak ada suplai tenaga listrik sampai proses perbaikan selesai, dikarenakan sistem jaringannya yang menggunakan konfigurasi jaringan radial tunggal yang mengharuskan jaringan dalam kondisi off pada saat perbaikan.

Berikut terlampir gambar event record yang terekam pada Relay UR-F35 GE Multilin pada saat Feeder 48 FDR-33 trip disebabkan oleh Arus Hubung Singkat Ground IOC (ground fault) setelah terjadinya gangguan phase to phase. 
105 Abdul Zain, Rifki Chairul Afwan. Analisis Gangguan Arus Hubung Singkat Trafo Distribusi 48-PT-33-7 Menggunakan ETAP (Studi Kasus Di Perumahan PT. Badak NGL)

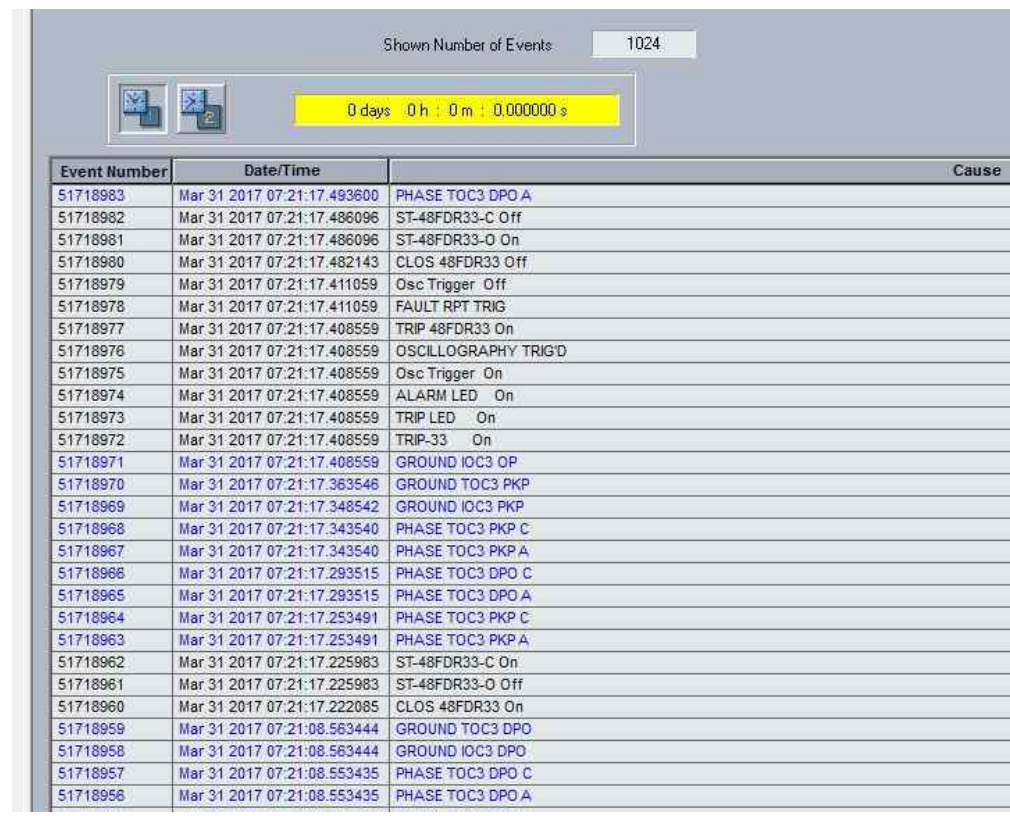

Gambar 6. Event Record pada saat Feeder 48-FDR-33 Trip disebabkan Arus Hubung Singkat Ground IOC

2. Hasil Preventif Maintenance 3 Tahunan Trafo 48-PT-33-7

Kegiatan PM rutin 3 tahunan untuk Trafo 48-PT-33-7 antara lain adalah pengujian Tahanan Isolasi dan pengujian Polarization Index. Kedua pengujian tersebut dilakukan untuk mendeteksi adanya kelemahan isolasi tahanan dan mencegah gangguan pada trafo terjadi. Sehingga trafo dapat dicegah dari terjadinya kegagalan/kerusakan secara mendadak dan dapat beroperasi dengan sebagaimana mestinya. Berikut terlampir hasil pengujian Polarization Index pada Trafo 48-PT-33-7.

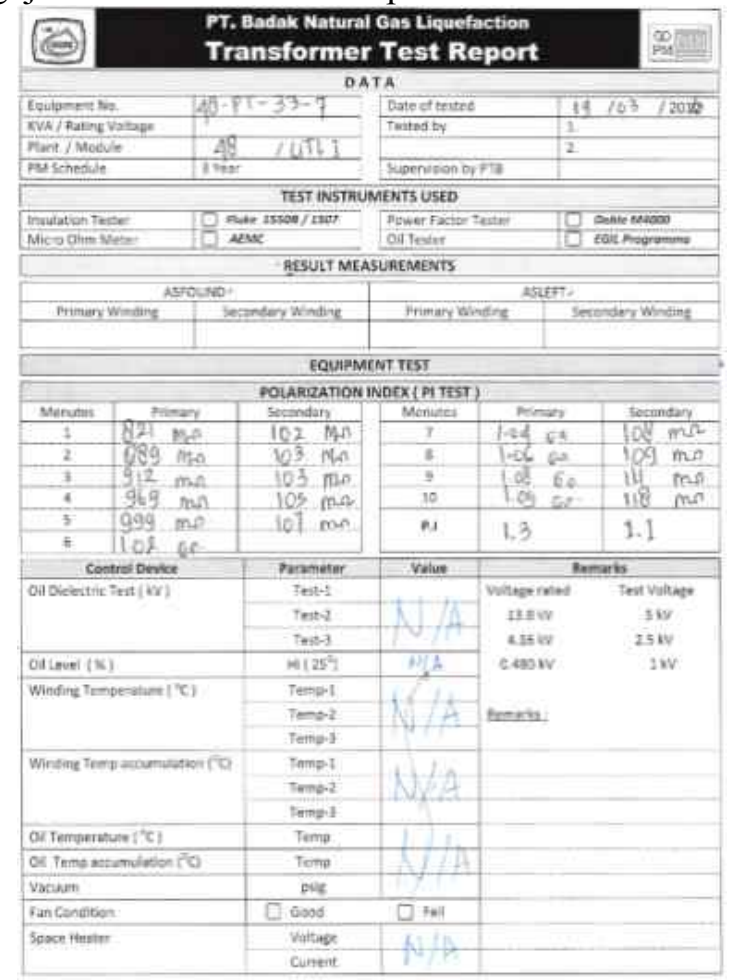




\section{Gaambar 7. Data Hasil PM 3 Tahunan Terakhir Trafo 48-PT-33-7}

\section{Hasil Perhitungan Manual Arus Hubung Singkat Trafo 48-PT-33-7}

Gangguan arus hubung singkat yang terjadi pada Trafo 48-PT-33-7 juga dirasakan di sisi pembangkit oleh Generator sampai mengakibatkan tripnya Feeder 48-FDR-33. Hal tersebut disebabkan oleh adanya arus hubung singkat fase ke ground yang tidak dapat diamankan di sisi Trafo. Sehingga gangguan terus mengalir ke sisi feeder dan pembangkit.

Dalam penelitian ini, gangguan arus hubung singkat yang dianalisa diambil yang terbesar, yakni yang dirasakan di sisi pembangkit. Sehingga nilai gangguan arus hubung singkat maksimumnya dapat diketahui. Untuk menghitung arus gangguan hubung singkat harus memiliki parameter yang menjadi acuan perhitungan yaitu tegangan pembangkit dan impedansi dari generator. Jika diketahui tegangan generator pada feeder 48-FDR-33 adalah $13,8 \mathrm{kV}$ dan daya hubung singkat pada Generator adalah 24,432 MVA, maka nilai arus gangguan hubung singkat adalah sebagai berikut :

a) Impedansi Sumber (Zs)

$$
\begin{aligned}
\text { Zdasar }=\frac{k V^{2}}{M V A}=\frac{13,8^{2}}{24,432}=7,51 \\
Z 1 \mathrm{~s}=\mathrm{Z} 2 \mathrm{~s}=\frac{\frac{k V^{2}(\text { Sumber })}{k V^{2}(\text { Bus })} \times \mathrm{Zdasar}=\frac{13,8^{2}}{13,8^{2}} \times 7,51}{=7,51 \angle 31,8^{4}}=6,3815+\mathrm{j} 3,9512
\end{aligned}
$$

b) Impedansi Trafo $\left(\mathrm{X}_{\mathrm{T}}\right)$, dengan nilai reaktansi sebesar 4\%, menggunakan persamaan

$$
\mathrm{XT} 1=\mathrm{XT} 2=4 \% \times \frac{k V^{2}(\text { Trafo })}{k \text { VA (Trafo })}=4 \% \times \frac{13,8^{2}}{500}=j 0,0152352
$$

c) Impedansi Saluran Feeder dengan panjang $(\mathrm{L})=3 \mathrm{~km}$

$$
\begin{array}{r}
\mathrm{Z} 1=\mathrm{Z} 2=\mathrm{L} \times \mathrm{Z}(\text { per km })=3 \times(0,0662+\mathrm{j} \mathrm{0,0379)} \\
=0,1986+\mathrm{j} 0,1137
\end{array}
$$

$\mathrm{Z} 0=\mathrm{L} \times \mathrm{Z}($ per $\mathrm{km}) \quad=3 \times(7,7973+\mathrm{j} 4,9321)$

d) Impedansi Ekivalen menggunakan persamaan

$$
=23,3919+\mathrm{j} 14,7963
$$

$$
\begin{aligned}
\mathrm{Zleq}=\mathrm{Z} 2 \mathrm{eq} & =\mathrm{ZS}+\mathrm{ZT}+\mathrm{Z1} \text { feeder } \\
& =6,3815+\mathrm{j} 3,9512+\mathrm{j} 0,01524+0,1986+\mathrm{j} 0,1137 \\
& =6,5801+\mathrm{j} 4,08014 \\
& =7,7424 \angle 31,8^{\circ}
\end{aligned}
$$$$
\mathrm{Z} 0 \mathrm{eq}=\mathrm{Z} 0 \quad=23,3919+\mathrm{j} 14,7963
$$

e) Arus gangguan hubung singkat

a.Arus gangguan hubung singkat 1 fase ke tanah

$$
\begin{aligned}
& \text { If }=\frac{3 x V L N}{Z 0+Z 1+Z 2}=\frac{3 \times \frac{13,8}{\sqrt{3}}}{23,3919+j 14,7963+2 x(6,5801+j 4,08014)} \\
& \qquad \frac{23,9022}{36,552+j 22,957} \\
& \cline { 2 - 3 }=\frac{23,9022}{43,16} \mid \\
& \cline { 2 - 3 }=0,5538 \mathrm{kA}=553,8 \mathrm{~A} \\
&
\end{aligned}
$$


107 Abdul Zain, Rifki Chairul Afwan. Analisis Gangguan Arus Hubung Singkat Trafo Distribusi 48-PT-33-7 Menggunakan ETAP (Studi Kasus Di Perumahan PT. Badak NGL)

b. Arus gangguan hubung singkat fase ke fase (dua fase)

$$
\begin{array}{|l|l|}
\cline { 2 - 2 } \multicolumn{1}{c|}{} & \text { If }=\frac{V L L}{Z 1+Z 2}=\frac{13,8}{2 x(6,5801+j 4,08014)} \\
=\frac{13,8}{2 x(6,5801+j 4,08014)}=\frac{13,8}{13,1602+j 8,1603} \\
=\frac{13,8}{15,48} \\
=0,89147 \mathrm{kA}=891,47 \mathrm{~A}
\end{array}
$$

c.Arus gangguan hubung singkat 2 fase ke tanah

$$
\begin{aligned}
& \text { If }=\frac{V L L}{Z 1+\frac{Z 2 x Z 0}{Z 2+Z 0}} \\
& =\frac{13,8}{(6,5801+j 4,08014)+\frac{(6,5801+j 4,08014) \times(23,3919+j 14,7963)}{(6,5801+j 4,08014)+(23,3919+j 14,7963)}} \\
& =\frac{(6,5801+j 4,08014)+\frac{228,97 \angle 64,11}{31,42 \angle 32,2^{\circ}}}{13,8} \\
& =\frac{1,5801+j 4,08014)+7,287 \angle 31,91^{\circ}}{(6,580} \\
& \begin{array}{|l|}
=\frac{13,8}{(6,5801+j 4,08014)+(6,19+j 3,85)} \\
=\frac{13,8}{(12,7701+j 7,93014)}=\frac{13,8}{15,03 \angle 31,84^{\circ}}
\end{array} \\
& =0,91816 \mathrm{kA}=918,16 \mathrm{~A}
\end{aligned}
$$

d. Arus gangguan hubung singkat 3 fase

$$
\begin{array}{r|}
\hline \text { If }=\frac{V L N}{Z 1} \\
=\frac{\frac{13,8}{\sqrt{3}}}{6,5801+j 4,08014} \\
\hline=\frac{7,9677}{7,74 \angle 31,8^{\circ}} \\
\hline=1,029412 \mathrm{kA}=1029,412 \mathrm{~A}
\end{array}
$$

Berdasarkan perhitungan manual, nilai arus gangguan hubung singkat (Isc) yang terjadi adalah 553,8 A untuk gangguan satu fase ke tanah, 891,47 A untuk gangguan dua fase (antar fase), 918,16 A untuk gangguan dua fase ke tanah dan 1029,4 A untuk tiga fase.

4. Hasil Perhitungan Gangguan Arus Hubung Singkat pada Trafo 48-PT-33-7 dengan Simulasi ETAP 12.6

Dengan melakukan simulasi menggunakan software ETAP pada jaringan feeder 48-FDR-33 (Switchgear Area 9) untuk Trafo 48-PT-33-7 diperoleh hasil perhitungan arus hubung singkat sebagai berikut.

a) Pengujian arus gangguan hubung singkat satu fase ke tanah. Hasil simulasi gangguan hubung singkat diperoleh nilai sebesar $555 \mathrm{~A}$. 


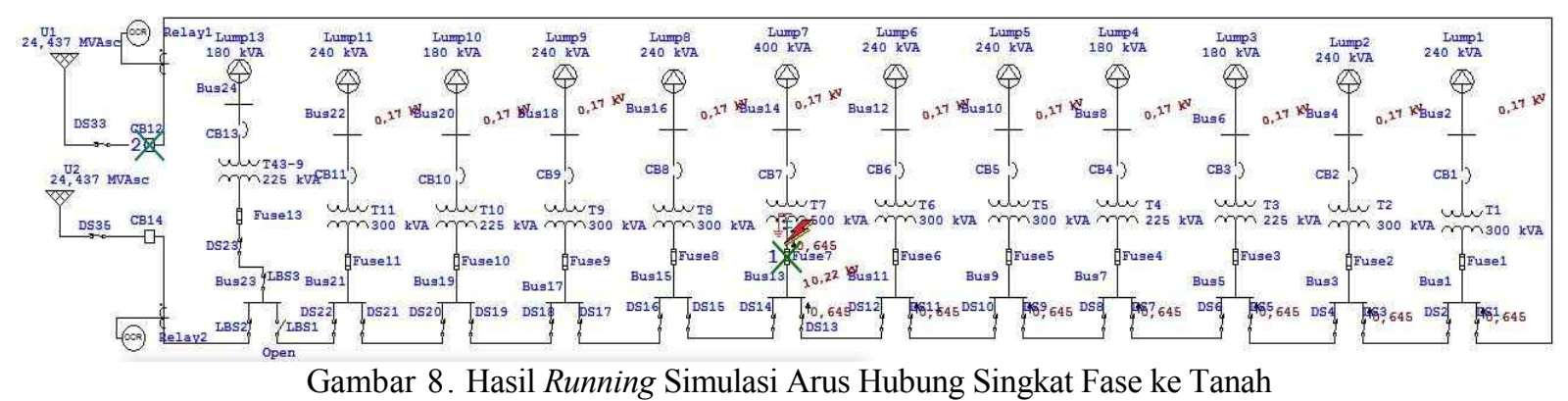

b) Pengujian arus gangguan hubung singkat dua fase (antar fase). Hasil simulasi gangguan hubung singkat diperoleh nilai sebesar $885 \mathrm{~A}$.

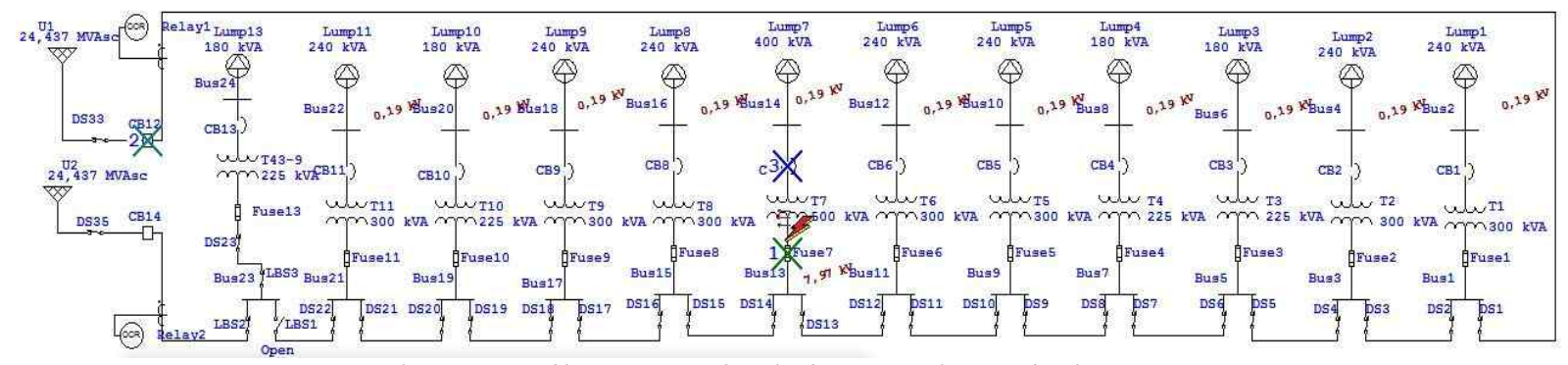

Gambar 9. Hasil Running Simulasi Arus Hubung Singkat Dua Fase

c) Pengujian arus gangguan hubung singkat dua fase ke tanah. Hasil simulasi gangguan hubung singkat diperoleh nilai sebesar 428 A ke tanah dan 950 A antar fase.

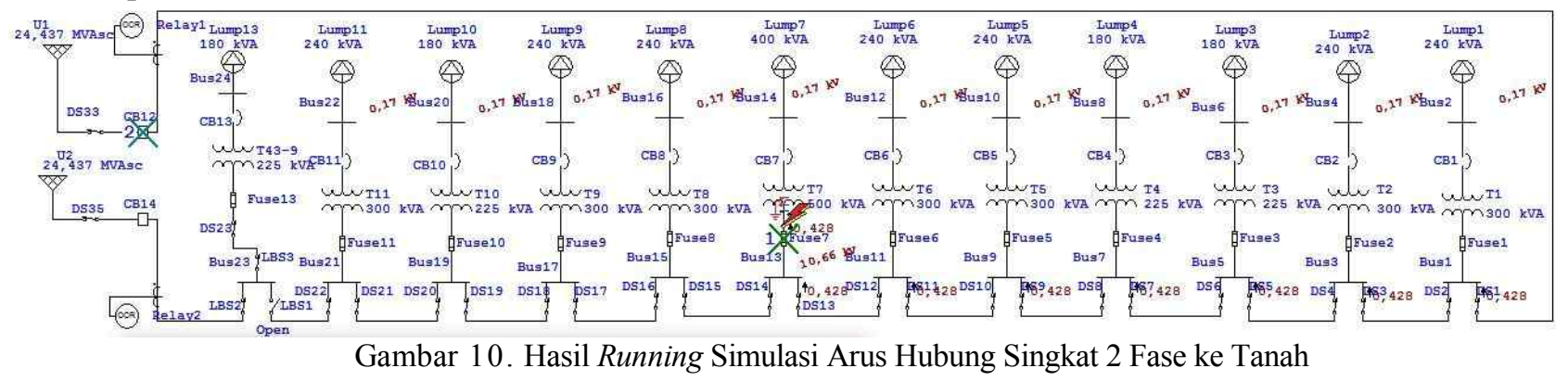

d) Pengujian arus gangguan hubung singkat tiga fase. Hasil simulasi gangguan hubung singkat diperoleh nilai sebesar $1022 \mathrm{~A}$.

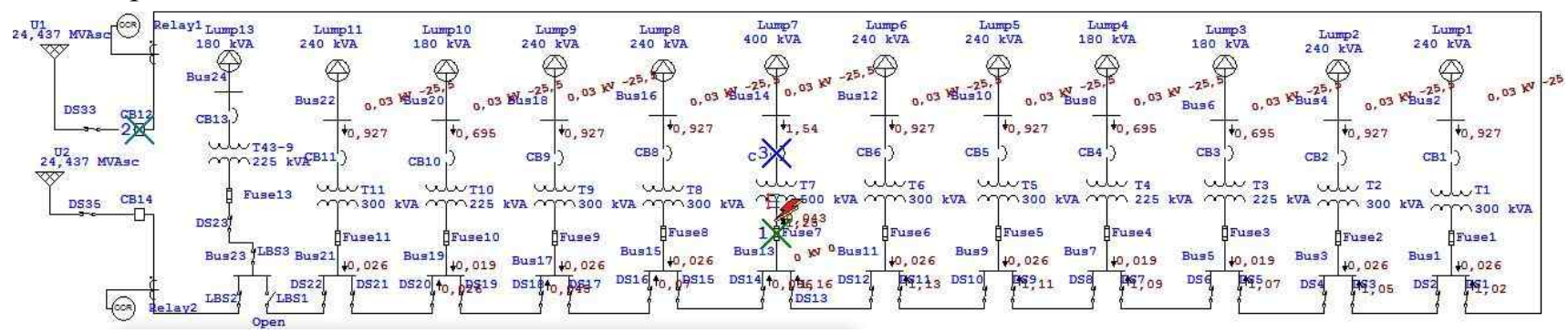

Gambar 11. Hasil Running Simulasi Arus Hubung Singkat 3 Fase

5. Analisis Penyebab Trip 48-FDR-33 yang terekam pada Relay UR-F35

Dari Event Record pada saat Feeder 48-FDR-33 Trip disebabkan oleh Arus Hubung Singkat Ground IOC dapat diketahui bahwa, gangguan mulai terdeteksi oleh relay pada saat indikasi "PHASE TOC3 PKP A dan PKP C", yang berarti bahwa telah terdeteksi gangguan pada fase A dan C (gangguan 
dua fase) mengakibatkan proses di relay pick up. Pick up artinya titik awal dimana besar gangguan mulai dirasakan oleh relay. Kemudian indikasi gangguan tersebut terus menerus sampai dengan terjadinya "GROUND IOC3 OP" yang berarti bahwa indikasi gangguan dua fase tadi juga terjadi terhadap arus bocor ke ground, sehingga mengakibatkan relay bekerja dan memberikan perintah kepada High Voltage Circuit Breaker untuk memutus rangkaian (Open). Pada akhirnya terjadilah trip pada Feeder 48-FDR-33 "TRIP48FDR33 On” (bagian yang ditandai lingkaran merah pada gambar di atas). Gangguan tersebut tidak dapat diamankan oleh Fuse di sisi Primer Trafo dikarenakan Fuse yang terpasang hanya berfungsi untuk mengamankan jaringan dari gangguan fase ke fase, bukan fase ke ground. Selain itu tidak adanya alat proteksi untuk mengamankan gangguan arus bocor ke ground yang dipasang di sisi Trafo. Sehingga akhirnya mengakibatkan gangguan tersebut terus mengalir ke sistem feeder nya yang dirasakan oleh relay UR F35.

Maintenance Electrical PSF Crew telah mencoba melakukan perbaikan pada Trafo 48-PT-33-7, namun hasil dari pengecekan di lapangan bahwa ditemukan kerusakan pada internal trafo yang mengakibatkan trafo harus diganti baru. Sehingga untuk perbaikan sementara dilakukan pemindahan beban Trafo 48-PT-33-7 di sisi sekunder ke Trafo 48-PT-33-11. Sehingga beban dapat kembali tersuplai tenaga listrik, dan untuk perbaikan sementara Trafo 48-PT-33-7 di isolasi sampai menunggu material pengganti trafo baru datang.

6. Analisis Data Pengujian Trafo 48-PT-33-7

Pada hasil pengujian tafo saat PM rutin 3 tahunan, data yang diperoleh mengindikasikan bahwa trafo sudah akan rusak berdasarkan nilai Polarization Index (PI) dan Tahanan Isolasi yang rendah tidak sesuai standar IEEE 43-2000 untuk performa trafo yang masih dalam kondisi bagus. Kondisi tersebut bisa terjadi dikarenakan faktor eksternal dan internal. Untuk faktor eksternal bisa disebabkan oleh lingkungan yang lembab, pengaruh temperatur, adanya moisture pada minyak, serangga dll. Sedangkan faktor dari internal disebabkan oleh faktor usia peralatan yang memang sudah mencapai usia maksimum pemakaian. Selain itu bisa juga disebabkan oleh pembebanan yang tidak seimbang antar tiap fase, pengaruh temperatur dan lamanya tegangan yang diterapkan pada lilitan.

7. Analisis Hasil Perhitungan Manual Arus Hubung Singkat

Berdasarkan perhitungan manual, nilai arus gangguan hubung singkat (Isc) yang terjadi adalah 553,8 A untuk gangguan satu fase ke tanah, 891,47 A untuk gangguan dua fase (antar fase), 918,16 A untuk gangguan dua fase ke tanah dan 1029,4 A untuk tiga fase. Dengan membandingkan arus gangguan tersebut nilai set point relay UR-F35 yaitu 51G TOC (27,9 A) dan 51 TOC (270 A) maka relay akan trip karena arus gangguan lebih besar dari set point.

8. Analisis Hasil Simulasi ETAP Arus Hubung Singkat

Dengan melakukan simulasi menggunakan software ETAP pada jaringan feeder 48-FDR-33 (Switchgear Area 9) untuk Trafo 48-PT-33-7 diperoleh hasil perhitungan arus hubung singkat sebagai berikut.

a) Pengujian arus hubung singkat satu fase ke tanah. Pada pengujian tersebut diperoleh nilai arus hubung singkat sebesar $555 \mathrm{~A}$. Dengan membandingkan arus gangguan tersebut dengan nilai setpoint relay UR F35 yaitu 51G TOC sebesar 27,9 A dan 51 TOC sebesar 270A maka tentunya Relay akan memerintahkan CB-12 untuk trip karena arus gangguan lebih besar dari set point. 


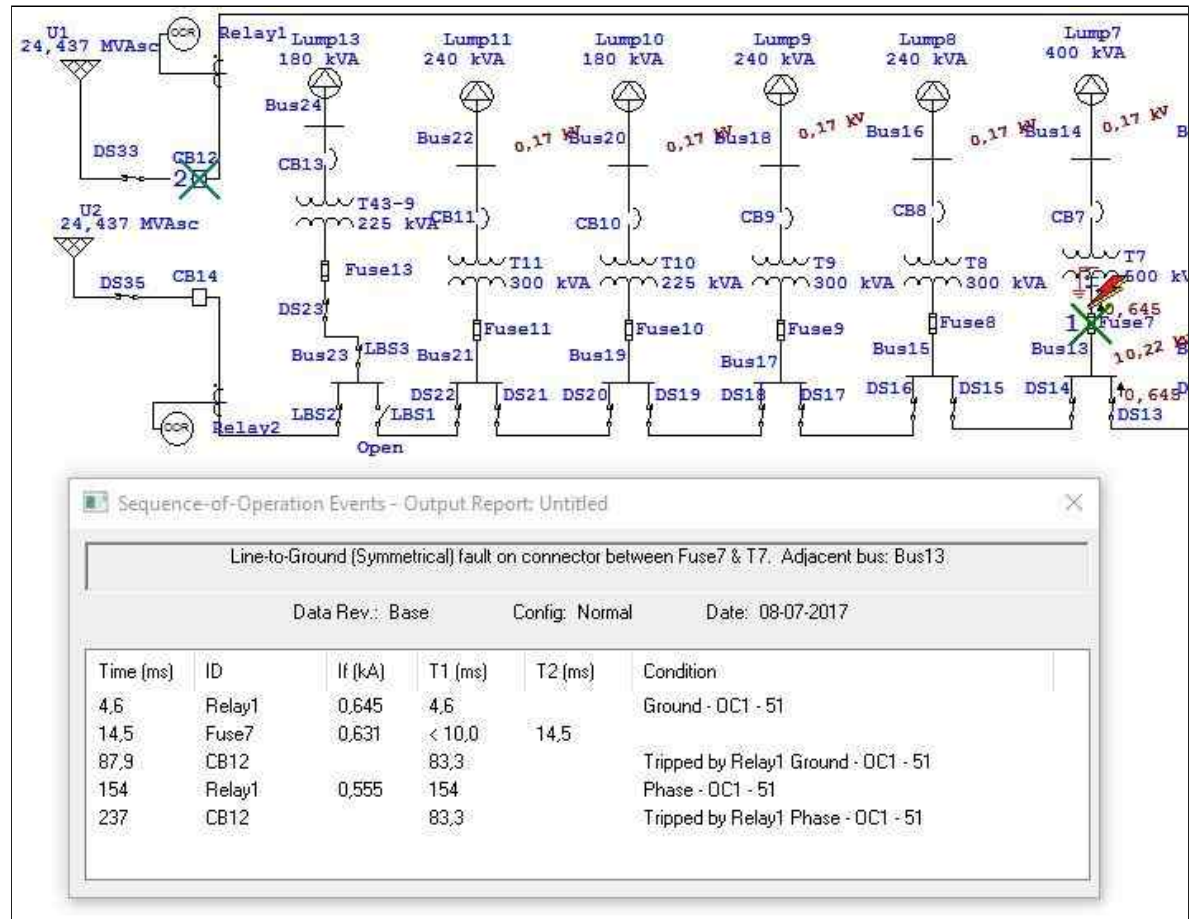

Gambar 12. Simulasi Arus Hubung Singkat Satu Fase ke Tanah

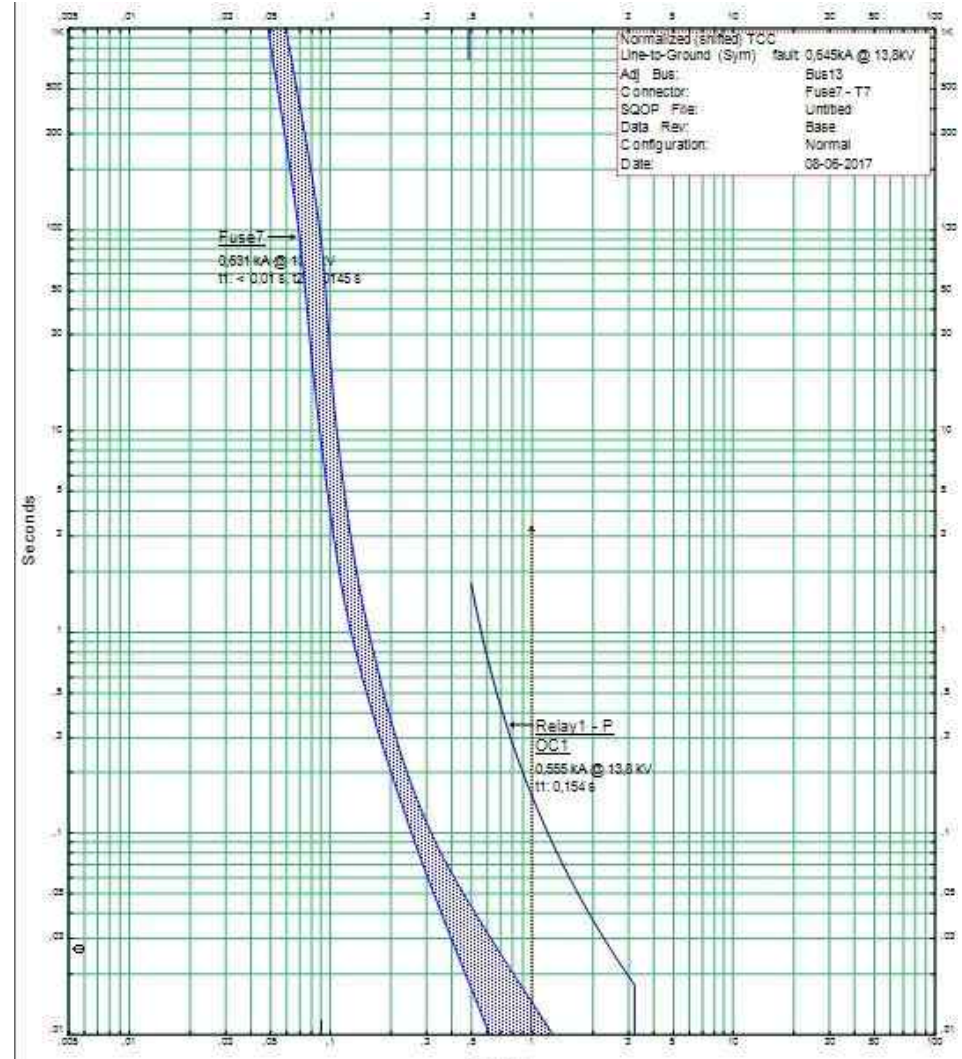

Per Unit

Gambar 13. Laporan Simulasi Arus Hubung Singkat Satu Fase ke Tanah 
111 Abdul Zain, Rifki Chairul Afwan. Analisis Gangguan Arus Hubung Singkat Trafo Distribusi 48-PT-33-7 Menggunakan ETAP (Studi Kasus Di Perumahan PT. Badak NGL)

Berdasarkan data gambar 12 dan 13, pada saat terjadi gangguan hubung singkat satu fase ke tanah diperoleh data pada Relay UR-F35. Gangguan pertama kali dirasakan yakni arus hubung singkat ke tanah oleh Sensor 51G TOC (Ground Time Overcurrent) sebesar 645 A dalam waktu 4,6 ms. Kemudian sensor pada relay tersebut memerintahkan CB 12 memutus aliran arus (trip) waktu 83,3 ms. Selain itu 51TOC (Time OverCurrent) juga bekerja merasakan gangguan hubung singkat fase sebesar 555 A dalam waktu $154 \mathrm{~ms}$. Selain relay UR F35, Fuse 7 bekerja memutus aliran dalam waktu kurang dari $10 \mathrm{~ms}$ dengan besar arus gangguan $631 \mathrm{~A}$ yang melebihi nilai set point nya sebesar 15A. Dari gambar one line diagram dan grafik tersebut juga diketahui bahwa urutan koordinasi sistem proteksi yang bekerja pertama kali adalah Fuse 7 dan kemudian CB-12 yang mendapat perintah dari relay.

b) Pengujian arus hubung singkat dua fase (antar fase). Pada pengujian tersebut diperoleh nilai arus hubung singkat sebesar $885 \mathrm{~A}$. Dengan membandingkan arus gangguan tersebut dengan nilai setpoint relay UR F35 yaitu 51 TOC sebesar 270A maka tentunya Relay akan memerintahkan CB-12 untuk trip karena arus gangguan lebih besar dari set point.
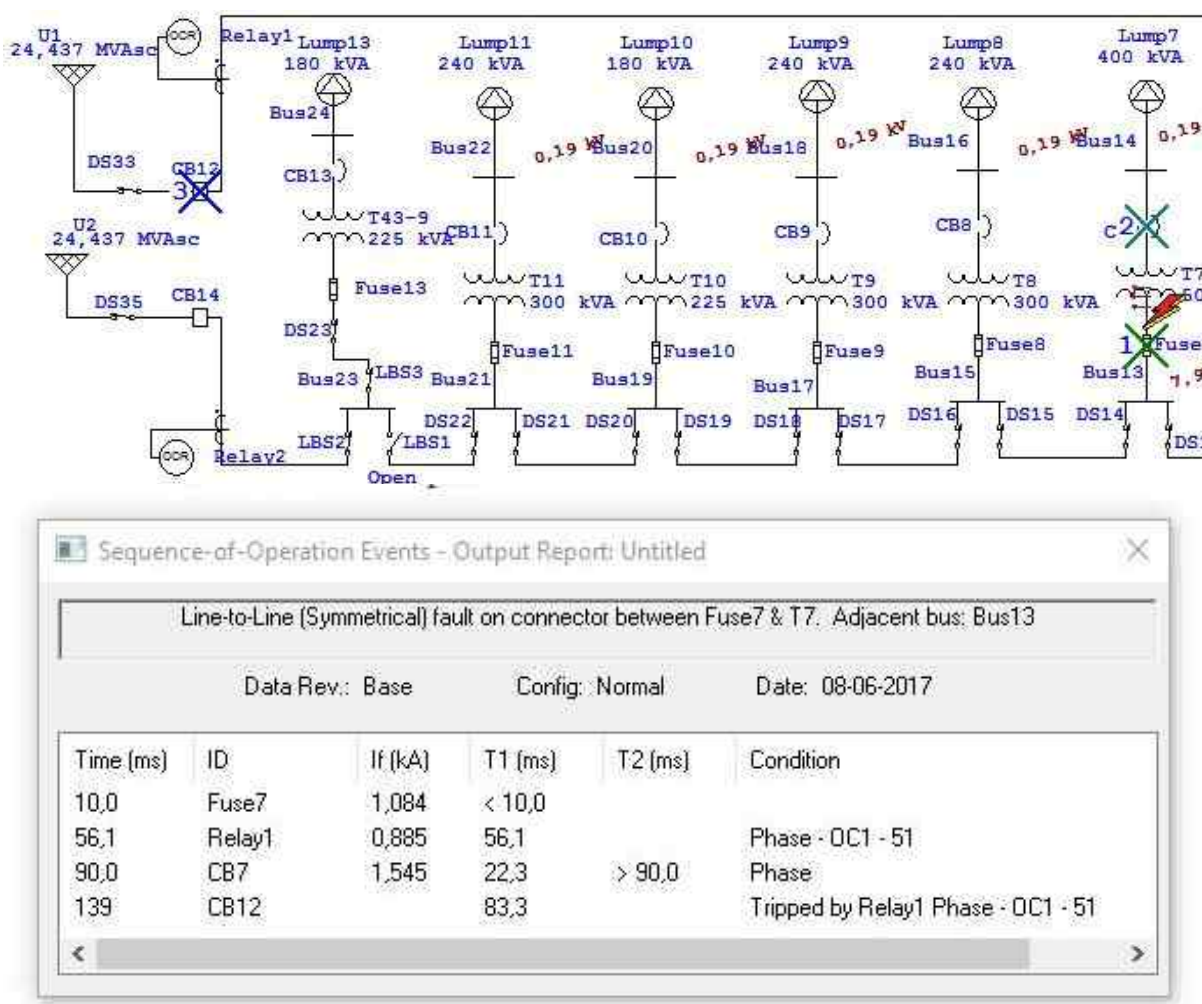

Gambar 14. Simulasi Arus Hubung Singkat Dua Fase 


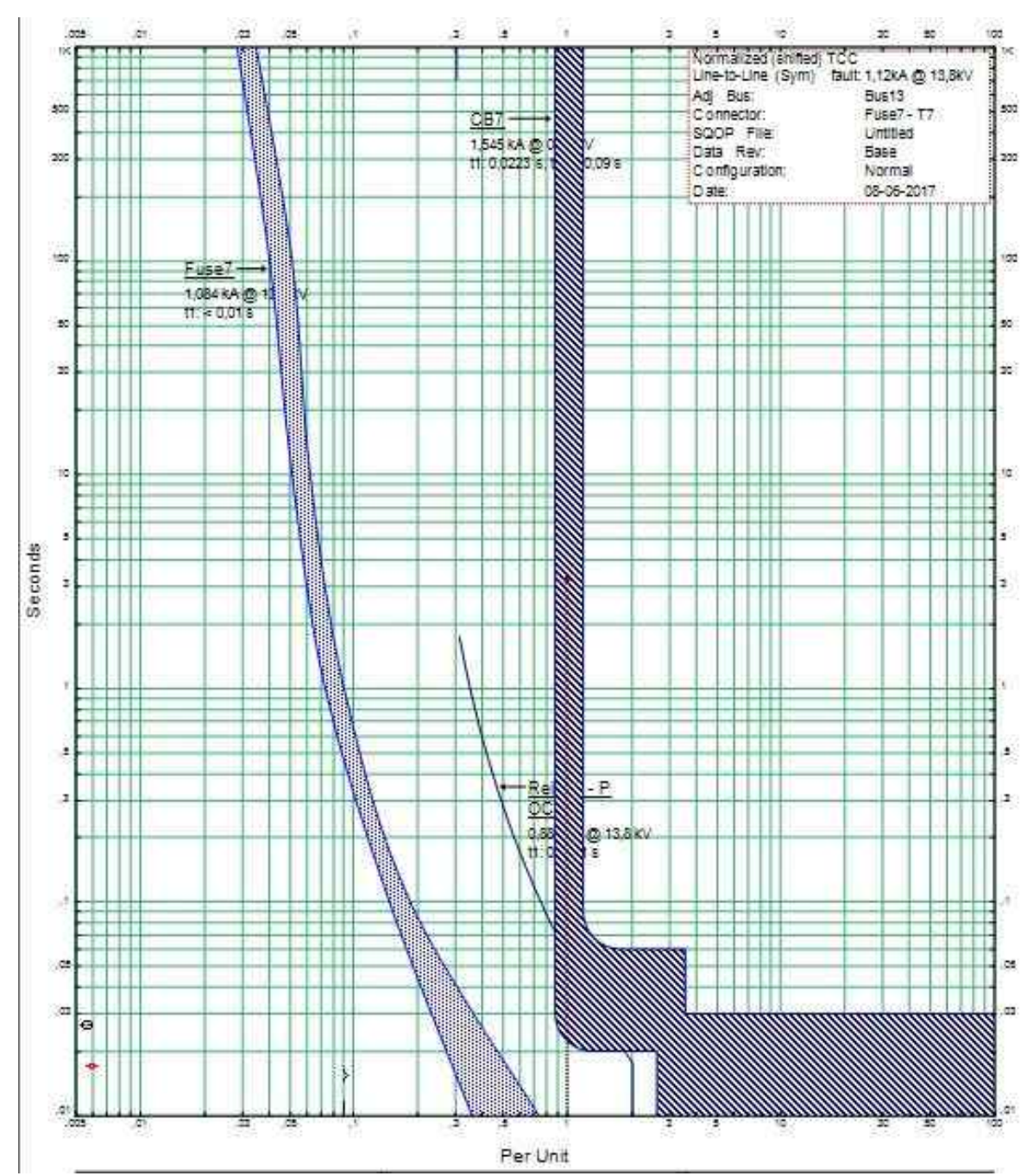

Gambar 15. Laporan Simulasi Arus Hubung Singkat Dua Fase

Berdasarkan data gambar 14 dan 15, pada saat terjadi gangguan hubung singkat dua fase diperoleh data pada Relay UR-F35. Gangguan pertama kali dirasakan yakni arus hubung singkat antar fase oleh Fuse 7 sebesar 1084 A dalam waktu 10 ms. Kemudian disusul oleh CB 7 sebesar 1545 A dalam waktu 22,3 ms. Setelah itu, gangguan terdeteksi oleh Sensor 51 TOC (Phase Time Overcurrent) sebesar 885 A dalam waktu 56,1 ms dan kemudian sensor pada relay tersebut memerintahkan CB 12 memutus aliran arus (trip) waktu 83,3 ms. Dari gambar one line diagram dan grafik tersebut juga diketahui bahwa urutan koordinasi sistem proteksi yang bekerja pertama kali adalah Fuse 7 dan kemudian CB-7 dan terakhir adalah CB-12 yang mendapat perintah dari relay.

c) Pengujian arus hubung singkat dua fase ke tanah. Pada pengujian tersebut diperoleh nilai arus hubung singkat sebesar 428 A ke tanah dan 950 A antar fase. Dengan membandingkan arus gangguan tersebut dengan nilai setpoint relay UR F35 yaitu 51G TOC sebesar 27,9A dan 51 TOC sebesar 270A maka tentunya Relay akan memerintahkan CB-12 untuk trip karena arus gangguan lebih besar dari set point. 
113 Abdul Zain, Rifki Chairul Afwan. Analisis Gangguan Arus Hubung Singkat Trafo Distribusi 48-PT-33-7 Menggunakan ETAP (Studi Kasus Di Perumahan PT. Badak NGL)

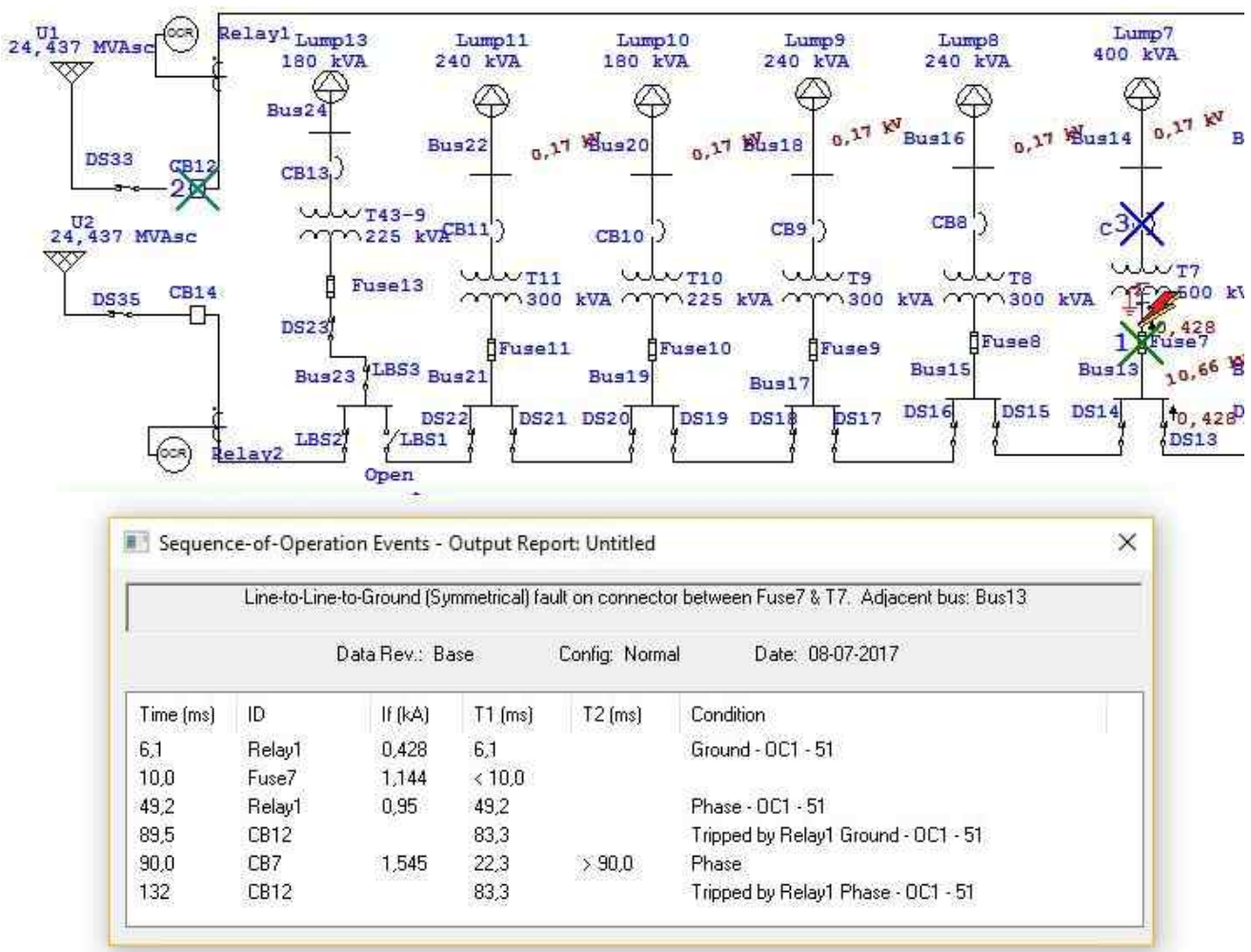

Gambar 16. Laporan Simulasi Arus Hubung Singkat 2 Fase ke Tanah

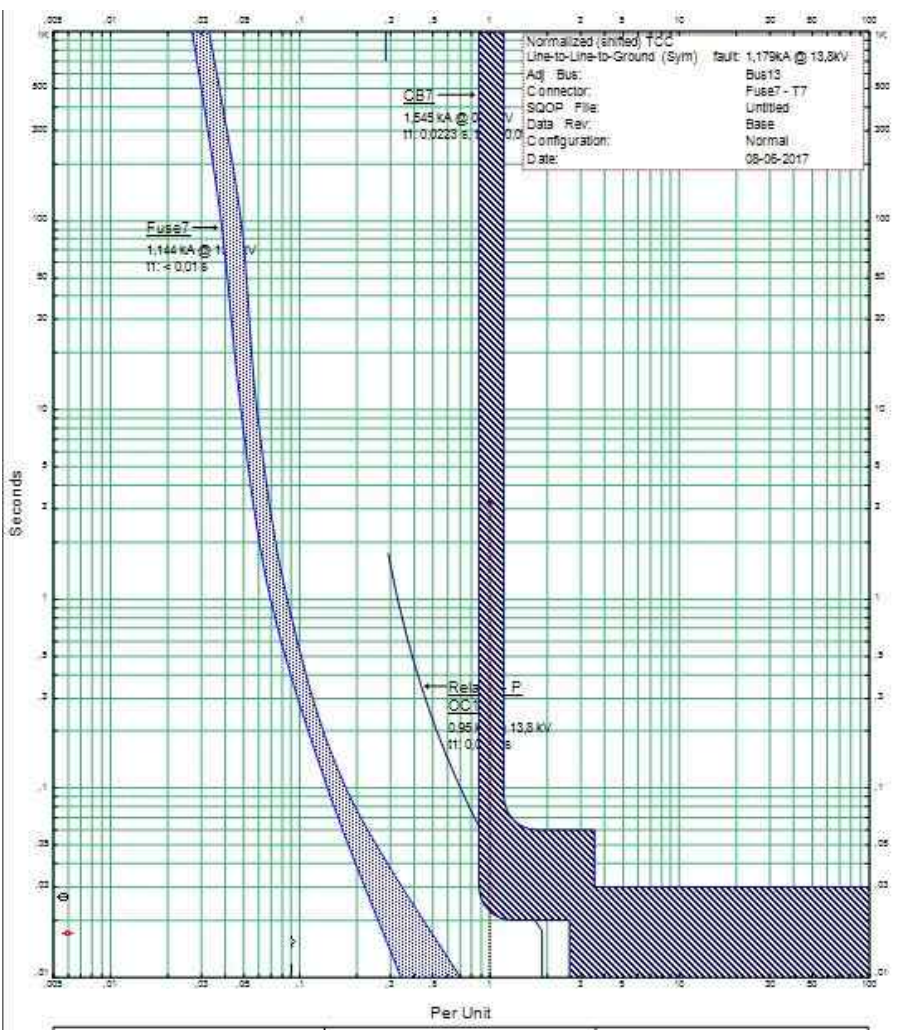


Gambar 17. Laporan Simulasi Arus Hubung Singkat 2 Fase ke Tanah

Berdasarkan data gambar 16 dan 17, pada saat terjadi gangguan hubung singkat dua fase ke tanah diperoleh data pada Relay UR-F35. Gangguan pertama kali dirasakan yakni arus hubung singkat ke tanah oleh Sensor 51G TOC 428 A dalam waktu 6,1 ms dan kemudian sensor pada relay tersebut memerintahkan CB 12 memutus aliran arus (trip) waktu 83,3 ms. Setelah itu, Fuse 7 bekerja mendeteksi gangguan sebesar 1144 A dalam waktu $10 \mathrm{~ms}$. Selanjutnya gangguan terdeteksi oleh Sensor 51 TOC (Phase Time Overcurrent) sebesar 950 A dalam waktu 49,2 ms. Dan terakhir dirasakan oleh CB 7 sebesar 1545 A dalam waktu 22,3 ms. Dari gambar one line diagram dan grafik tersebut juga diketahui bahwa uru tan koordinasi sistem proteksi yang bekerja pertama kali adalah Fuse 7 dan kemudian Relay 51G TOC melalui CB-12 dan terakhir adalah CB-7.

d) Pengujian arus hubung singkat tiga fase. Pada pengujian tersebut diperoleh nilai arus hubung singkat sebesar $1022 \mathrm{~A}$ antar fase. Dengan membandingkan arus gangguan tersebut dengan nilai setpoint relay UR F35 yaitu 51 TOC sebesar 270A maka tentunya Relay akan memerintahkan CB-12 untuk trip karena arus gangguan lebih besar dari set point

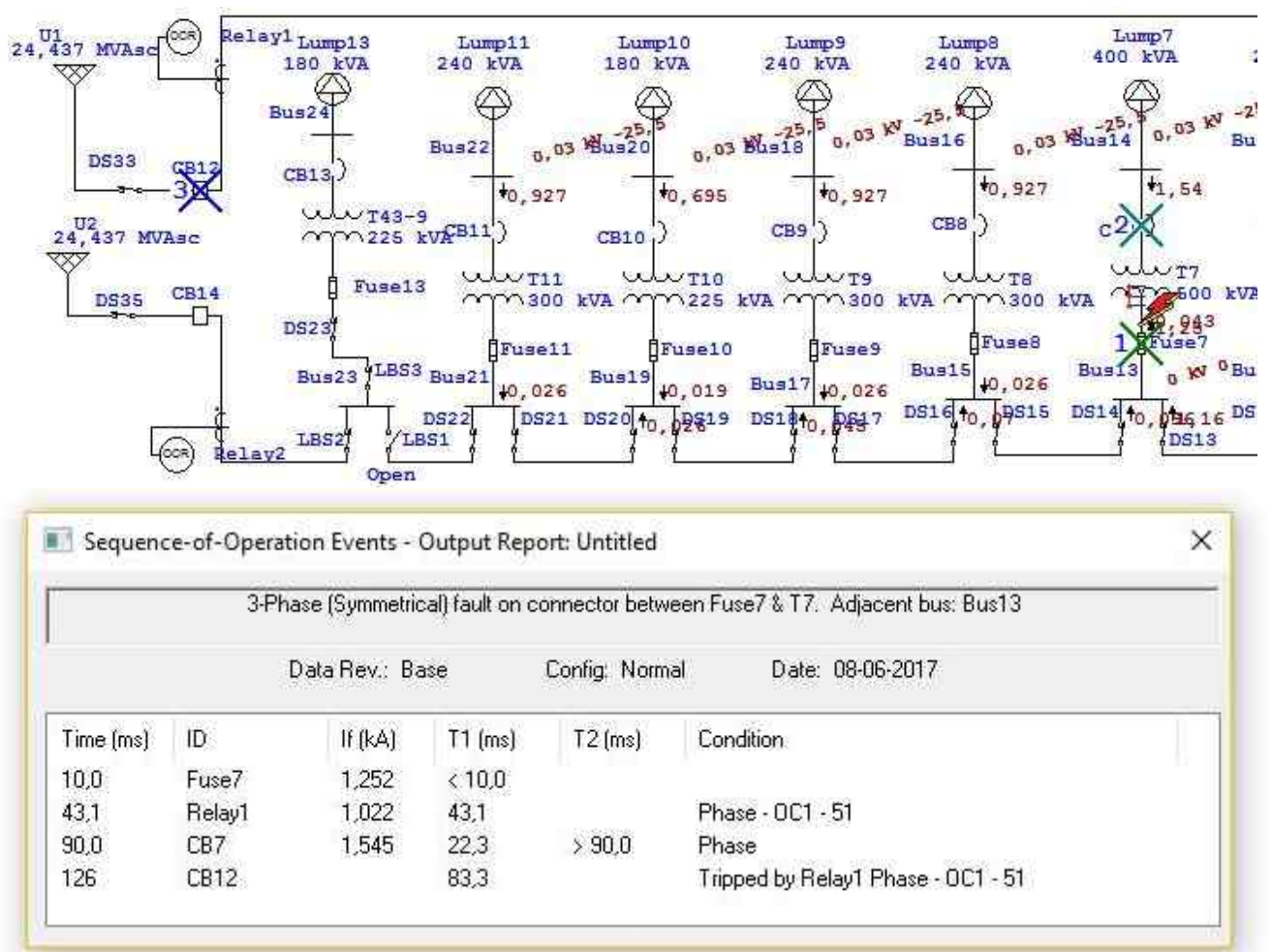

Gambar 18. Simulasi Gangguan Arus Hubung Singkat 3 Fase 
115 Abdul Zain, Rifki Chairul Afwan. Analisis Gangguan Arus Hubung Singkat Trafo Distribusi 48-PT-33-7 Menggunakan ETAP (Studi Kasus Di Perumahan PT. Badak NGL)

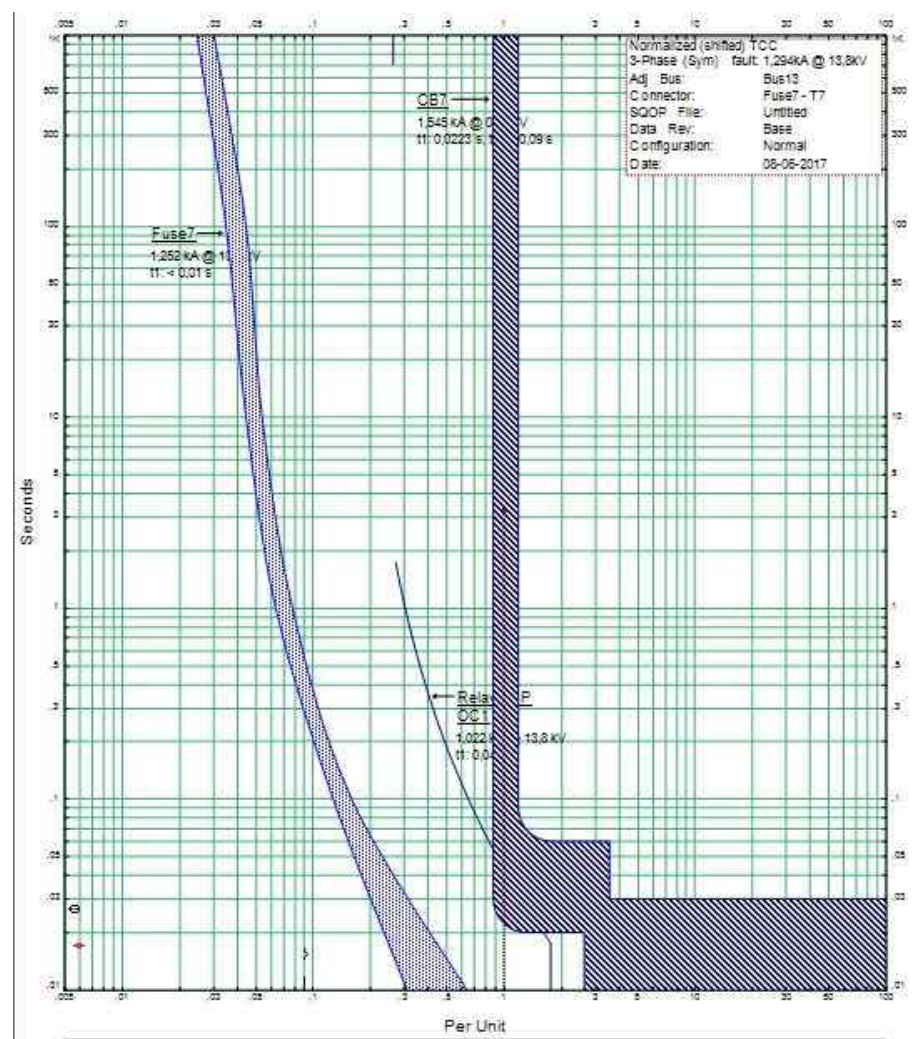

Gambar 19. Laporan Simulasi Gangguan Arus Hubung Singkat 3 Fase

Berdasarkan data gambar 18 dan 19, pada saat terjadi gangguan hubung singkat tiga fase diperoleh data pada Relay UR-F35. Gangguan pertama kali dirasakan yakni arus hubung singkat antar fase oleh Fuse 7 sebesar 1252 dalam waktu 10 ms. Selanjutnya CB-7 sebesar 1545 A dalam waktu 22,3 ms. Terakhir gangguan dirasakan oleh Sensor 51 TOC sebesar 1022 A dalam waktu 43,1 ms dan kemudian sensor pada relay tersebut memerintahkan CB 12 memutus aliran arus (trip) waktu 83,3 ms. Dari gambar one line diagram dan grafik tersebut juga diketahui bahwa urutan koordinasi sistem proteksi yang bekerja pertama kali adalah Fuse 7 dan kemudian CB-7 dan terakhir adalah Relay 51 TOC melalui CB-12.

\section{KESIMPULAN}

Berdasarkan analisis hasil simulasi pada penelitian ini, dapat diambil kesimpulan :

1. Alat proteksi yang terpasang pada sisi Trafo 48-PT-33-7 yakni Fuse berkapasitas 15A hanya dapat mengamankan gangguan arus gangguan hubung singkat antar fase. Sehingga ketika terjadi gangguan arus hubung singkat fase ke tanah terjadi mengakibatkan feeder 48-FDR-33 terganggu dan trip.

2. Perhitungan arus gangguan hubung singkat secara manual maupun dengan simulasi software ETAP 12.6, diperoleh hasil yang relatif sama besar nilainya. Yakni untuk arus gangguan satu fase ke tanah sebesar 553,8 A (Manual) dan 555 A (ETAP). Dua fase sebesar 891,47 (Manual) dan 885 A (ETAP). Dua fase ke tanah sebesar 918,16 (Manual) dan 950 (ETAP). Tiga fase sebesar 1029,41 (Manual) dan 1022 (ETAP). Sehingga kedua metode tersebut relevan untuk digunakan dalam menentukan besarnya nilai arus gangguan hubung singkat yang akhirnya diperuntukan dalam menentukan setting alat proteksi yang sesuai. 
3. Hasil simulasi menunjukan bahwa urutan koordinasi sistem proteksi yang terpasang sudah bekerja sebagai mestinya. Dengan demikian relay UR-F35 GE Multilin telah beroperasi sesuai dengan spesifikasinya yang dapat mengamankan feeder 48-FDR-33 dari gangguan arus hubung singkat.

\section{UCAPAN TERIMA KASIH}

Penulis menyampaikan terima kasih kepada seluruh pihak yang telah memberikan kontribusi yang positif bagi penyelesaian penelitian ini yakni :

1. Manajer dan Karyawan PT. Badak NGL Bontang khususnya Electrical Section, Maintenance Department

2. Pimpinan Stitek Bontang

3. Ketua LPPM Stitek Bontang

4. Dosen dan Staf Stitek Bontang

\section{DAFTAR PUSTAKA}

[1] Zainal, Anton. 2015. Analisis Gangguan Arus Hubung Singkat pada Feeder 48-FDR-28 (Mini Power) Di PT Badak NGL Bontang. Tugas Akhir tidak diterbitkan. Program Studi Teknik Elektro, STITEK Bontang

[2] Widianto, Fajar.2013. Analisis Gangguan Hubung Singkat Tiga Fase pada Sistem Distribusi Standar IEEE 13 Bus dengan menggunakan Program ETAP Power Station 7.0. Fakultas Teknik, Jurusan Teknik Elektro, Universitas Muhammadiyah Surakarta

[3] Sinaga, Herman H., Henry B. H. Sitorus dan Risky. 2008. Analisis Karakteristik Gangguan Hubung Singkat Antar Belitan Transformator Menggunakan Transformasi Wavelet Diskrit. Tugas Akhir. Universitas Lampung. Bandar Lampung

[4] Firdausi, Mega. 2015. Analisis Koordinasi Relay Arus Lebih dan Penutup Balik Otomatis (Recloser) pada Penyulang Junrejo $20 \mathrm{kV}$ Gardu Induk Singkaling Akibat Gangguan Arus Hubung Singkat. Tugas Akhir. Universitas Brawijaya. Malang

[5] Rahim, Aulia. 2011. Studi Hubung Singkat Untuk Gangguan Simetris dan Tidak Simetris Pada Sistem Tenaga Listrik PT. PLN P3B Sumatera, Teknik Elektro Fakultas Teknik, Universitas Andalas Padang

[6] Glover D J., Sarma S. M., Overbye J. T., 2008. Power System Analysis and Design 4th. Thomson Corp. 